\title{
Interest in the Management Accounting Profession: Accounting Students' Perceptions in Jordanian Universities
}

\author{
Khaled Abed Hutaibat \\ Accounting Department, Mu'tah University \\ P.O.Box 2116, Tla Al-Ali 11953, Amman, Jordan \\ E-mail: Hutaibat@mutah.edu.jo,Hutaibat@hotmail.com
}

Received: August 24, 2011

Accepted: October 9, 2011 Published: March 1, 2012

doi:10.5539/ass.v8n3p303

URL: http://dx.doi.org/10.5539/ass.v8n3p303

\begin{abstract}
This study is a first attempt seeking to explore perceptions of accounting students regarding their interest in the management accounting profession. Furthermore, this study aims to discuss and clarify the main factors that have already influenced and may influence in future students' interest to pursue a professional qualification in management accounting. The study has considered and used the theory of planned behaviour in examining the factors that influence students' interest to major or not to major in a particular discipline. The sample of this exploratory study was final year accounting students of two reputable Jordanian universities. Based on a questionnaire survey, data of 118 respondents were used for analysis. The study's findings show that accounting students prefer public accounting as their first choice of career, rather than management accounting. Job opportunities and income were the most important factors that discouraged students to be interested in the management accounting profession. On the other hand, it was suggested that support from companies to pursue the management accounting profession was the most important factor suggested to enhance students' interest in this branch of the accounting profession.
\end{abstract}

Keywords: Interest, Management accounting, Jordanian universities, Accounting students

\section{Introduction}

Management accounting as a discipline, profession and practice has recently been given a considerable amount of unwanted attention, since renowned accounting academics have considered both the academic discipline and the professional practice as a 'dated' concept (Langfield-Smith, 2008; Milne et al., 2008; Otley, 2008). Otley (2008), for instance, suggests that financial management and analysis exist but that middle management often undertake such analyses themselves, thus do not need a designated accounting professional for this purpose. At the same time, in the modern and dynamically global business environment, the possession of accurate accounting information becomes vital, especially in circumstances of intense global competition, scarce resources, accelerating technological changes, and the existence of varying concerns for business managers (such as accountability, transparency, corporate governance, business ethics). In light of these factors, the need for financial management and analysis is apparent, yet simultaneously the perceived relevance of management accounting appears to be diminishing (Otley, 2008). Baldvinsdottir et al. (2010), on the other hand, call for more research on management accounting in practice, which this paper seeks to answer to by investigating how Jordanian accounting students perceive the opportunity to become a management accountant in practice.

In general, there is less emphasis on and interest in the management accounting profession as compared to the financial accounting profession, which might be justified by the two main differentiating factors: managerial accounting is meant for internal use, for instance in support of planning, directing and motivating, controlling and performance evaluation purposes, and it is optional, except for cost calculations, such as production cost (Hopper et al., 2007). Nevertheless, businesses face continuing challenges, such as global competition and the effects of global developments and events, which can affect their profitability, arguably one of the main aims of any for-profit organisation. While Otley (2008) argues that the conceptual category of management accounting appears to be no longer applicable in practice or in academia, the questions arises as to why this is the case. Hoffjan et al. (2009) argue that culture and perceptions of the concept, discipline and profession affect how management accounting practices are adopted and utilised. Otley (2008) does not qualify whether his beliefs 
apply to all possible management accounting users, but one can assume that primarily the Anglo-Saxon market is concerned. In stark contrast to his suggestions regarding the conceptual category are the recent developments taking place in practice. The Chartered Institute of Management Accountants (CIMA), UK-based, and the American Institute of Certified Public Accountants (AICPA), US-based, have agreed on a joint venture, which will result in a new professional qualification, the Chartered Global Management Accountant (CGMA), and is expected to increase management accounting's profile in the North American market and is meant to promote management accounting's development in the US (CIMA, 2011). Arguably, CIMA is the most prestigious management accounting professional qualification, and, while not as high profile as its more financial accounting and auditing-oriented competitors, it proves a real career alternative in the UK market. Yet, beyond those borders, it is relatively little known (Hoffjan et al., 2009).

In developing markets, getting an international accounting certification, in addition to a university degree, would increase workforce mobility. In addition, management accounting is truly flexible, as practices do not adhere to country-specific standards and regulations (Drury, 2008). In general, becoming an accountant is considered an elitist and highly regarded career choice (Gammie and Kirkpatrick, 2008). The accounting profession is a really popular career choice by Jordanian students and their parents alike, as it is associated with good job opportunities (see Ahmed et al., 1997). Among the most popular professional certificates are the American Certified Public Accountant (CPA), the Jordanian Certified Public Accountant (JCPA) (Hutaibat, 2005) and recently the Association of Chartered Certified Accountants (ACCA), but management accounting and a related qualification are not as desirable (Hutaibat, 2005). Hutaibat (2005) found management accounting practices in Jordanian organisations to be lacking, and the question arises whether there is a link to formal education.

In order to solve a problem, one has to go back to the root and identify the real issue. The most recent users of accounting in general and management accounting in particular are students in universities and colleges across the world. Future professionals are the output of their educational experience, and beliefs, valuation and behavioural features regarding their profession and its practices are strongly embedded in official education (Bourdieu, 1990). The root of the problem lies partially in the educational context, which reiterates the focus on financial, rather than managerial, accounting. Typically, management accounting is considered to be dominated by financial accounting (Hopper et al., 1992). Management accounting is one of the main fields of accounting, and it plays a very important role within companies in all industry sectors (e.g. manufacturing and services). This paper argues that the level of interest in management accounting in practices is associated with level of emphasis that universities students put on management accounting qualifications. This leads to the following question: to which extent are current accounting students at universities willing to be prepared and to be equipped with the best knowledge pursue a career in management accounting. The focus of this paper is on the perceptions of universities student to explore and to discuss the main factors that may influence the students' interest to pursue a professional qualification in management accounting. Often these include family, friends, labour market and of course the university, as each of these pass on their beliefs of accounting systems and practices (Bourdieu, 1990).

Usually interest is initiated at student level or after graduation, and when practicing accounting in the workplace. Many studies in accounting have examined the interest of business students in accounting as a major and as a future career (see Saemann and Crooker, 1999; Ahmed et al., 1997; Felton et al., 1994). According to the researcher's knowledge, no one has investigated the interest of accounting students in a particular accounting career, such as becoming a management accountant. Thus, it is very important to study accounting students' interest in management accounting as a promising future career. Particularly in light of recent concerns regarding management accounting (Otley, 2008), it is important to determine what the future outlook of management accounting as a concept and as a profession is expected to be. Furthermore, the need and the importance of carrying out more research on management accounting has been emphasised by many researchers over the last two decades (Otley, 1983; Scapens et al., 1983; Drury and Tayles, 1995; Drury and Tayles, 1994; Brierley et al., 2001; Haldma and Lääts, 2002; Baldvinsdottir et al., 2010).

The need for accounting graduates is growing, therefore their perceptions of future opportunities are very important. Most accounting studies, such as McKenzie (1992), Felton et al. (1994), Nelson et al. (2002), and Warrick et al. (2010), examined student perceptions in a variety of accounting fields except management accounting. The purpose of this study is to supplement this limited research on accounting student perceptions of career opportunities in management accounting, and identify the significant factors affecting the career decisions of accounting students in two large universities in Jordan. The results of this study will be useful to employers and professional accounting bodies, such as CIMA, the Institute of Management Accountants (IMA) and the 
Jordanian accounting bodies, by providing information on accounting students' perceptions and identifying the factors that influence their future career and profession.

The current study considers and uses one of the most popular conceptual frameworks, the theory of planned behaviour, for analysing the interest of accounting students in the management accounting profession. Using this theoretical framework provides a better understanding of students' interest in the management accounting profession and the factors that influence such interest, for instance personal beliefs, referents, and control factors (see Ajzen, 2002).

The remainder of this paper is outlined as follows. The next section reviews prior related studies and develops the study's hypotheses. Next, research methodology and data collection are discussed. Then, research results and discussion of results are then presented. Finally, the last section presents conclusions, limitations and future research.

\section{Review of prior studies and hypotheses development}

Hutaibat (2005) in his investigation of management accounting practices within Jordanian manufacturing companies pointed out the lack of use of management accounting techniques and the lack of interest among practitioners in management accounting qualifications and profession.

Prior research has identified that management accounting has a lower perceived value than financial accounting. The results of prior studies have pointed out that management accounting professional certificates, such as the Certified Management Accountant (CMA) and CIMA, were not popular and desired among practicing accountants and accounting students world-wide compared with other, more financial accounting-oriented, professional accounting certificates. For example, Warrick et al. (2010) in their study of junior and senior accounting students at a southern public university in the USA found that most students (about $76 \%$ ) were interested in pursing the Certified Public Accountant (CPA), rather than CMA, in which only $12 \%$ indicated their interest to purse after graduation. Similarly, Nelson et al. (2002) also pointed out the preference to pursue the CPA certificate over other accounting certificates among accounting students in the USA (see also Giladi et al. 2001). Moreover, Joshi et al. (2008) found that most respondents, of their exploratory study of Bahrain's accounting and auditing professionals, prefer and hold the CPA certificate with $44 \%$, only $6 \%$ of respondents hold the CMA certificate, and none the CIMA certificate. However, The UK sector is the only sector that provides a highly sought-after management accounting professional qualification, and the German sector greatly emphasises management accounting in practice, albeit based on university qualification only (Hoffjan et al. 2009).

In Jordan, Hutaibat (2005) found that both CMA and CIMA were not popular and attractive to the profession at all. This was evident from the findings of his study, which showed that none of the accountant respondents of the 133 large and medium Jordanian manufacturing companies hold such professional certificates. His study also found that the American CPA was the most commonly held professional accounting qualification in respondent companies, followed by the Jordanian Certified Public Accountant (JCPA) qualification. Hutaibat found that the majority (56\%) of respondents considered the level of development of management accounting profession in Jordan as a 'low' and 'very low' level of development and only $8 \%$ considered it as a 'high' level of development.

Many researchers have conducted and examined students' perceptions in a variety of accounting fields and concentrated on students' interest on majoring and choosing accounting as their future career and the factors that influence such interest, but none has investigated the interest in management accounting as a future career and profession (for example see, Hermanson and Hermanson, 1995; Ahmed et al., 1997; Saemann and Crooker, 1999; Tan and Laswad, 2006; James and Hill, 2009; Warrick et al., 2010).

Factors that influence students' interest in particular majors vary. Intellect, personal styles, job prospects, family background, parental pressures, perceptions of different disciplines, culture, market focus and the curricular options made available by universities are categories of such factors (see Bourdieu, 1990; Wolk and Cates, 1994; Simons et al., 2004; Tan and Laswad, 2006; Hoffjan et al., 2009). A consistent result of many prior studies points out the important impact of financial factors (e.g. job opportunities and income) upon accounting students' decisions when choosing their majors (see for example, Gul et al., 1989; Inman et al., 1989; Adams et al., 1994; Felton et al., 1994; Lowe and Simons, 1997; Mauldin et al., 2000; Ahmed et al., 1997). Similarly, the market's and sector's perception of a particular accounting branch plays an important role. German companies, for instance, place great emphasis on financial information for planning purposes but management accountants typically do not engage in planning and decision-making; they merely review and ensure that planning and decision-making take place (Hoffjan et al., 2009). The Anglo-Saxon management accountant, on the other hand, 
is responsible for and coordinates the decision-making and planning process (Granlund and Lukka, 1998; Pierce and O'Dea, 2003; Hoffjan et al., 2009).

Formal education has a great effect on the creation of perceptions and opinions, and the reiteration and reinforcement of particular views (Bourdieu, 1990), such as the dominance of financial accounting (Hopper et al., 1992). The influence of introductory accounting courses upon accounting students' perceptions of the profession has been examined by many scholars (see Adams et al., 1994; Stice and Swain, 1997). Such influence could encourage or discourage them from majoring in accounting, depending on how they perceive those courses. Inman et al. (1989) and Saemann and Crooker (1999) point out that students choose to major in the accounting discipline more likely when they perceive it as interesting and enjoyable. Another study by Mauldin et al. (2000) indicates the important impact of the first accounting principles course on the students' decision to choose accounting as their major. The influence of a heavy workload of accounting courses upon students' interest in the accounting major was one of the issues that many studies have investigated and pointed out its negative impact (see for example, Cohen and Hanno, 1993; Allen, 2004; Saemann and Crooker, 1999).

Other factors may also impact on students' choice of their future profession, such as accounting instructors, parents, relatives, or friends. Inconsistent findings were reported in literature. Cangelosi et al. (1985) and Gul et al. (1989) did not find that instructors have an important impact on students' choice of majors. Other studies (see for example, Hermanson and Hermanson, 1995; Geiger and Ogilby, 2000; Mauldin et al., 2000) indicate the significant importance of accounting instructors upon students' decisions in choosing the accounting major and profession. Cangelosi et al. (1985), Gul et al. (1989), Hermanson and Hermanson (1995), and Lowe and Simons (1997) indicated that friends and parents were less influential upon students' decision-making. On the other hand, Inman et al. (1989) and Mauldin et al. (2000) indicate the important influence of parents and accounting instructors upon students' decisions in choosing the accounting major. However, Cohen and Hanno's (1993) study indicates that most prior studies did not present a theoretical justification for studying the influence of such factors, which makes it difficult for generalising such results.

Therefore, the current study considers and uses the so called 'theory of planned behaviour' (TPB), which has been used by many prior studies to study human action and predict various behaviours, such as choosing a career and job seeking behaviour (see Cohen and Hanno, 1993; Ajzen, 2001). Such general theoretical model of behaviour appears to be the appropriate and suitable framework for studying accounting students' interest, intentions and choice of their future profession (Cohen and Hanno, 1993; Allen, 2004; Tan and Laswad, 2006).

The TPB was developed by Ajzen (1988), which is an expansion of the theory of reasoned action (TRA), developed by Fishbein and Ajzen (1975). Both theories study attitudes, subjective norms, intentions and target behaviour. The TPB hypothesises that people take action according to their intentions and perceptions of control over their behaviour, while intentions sequentially are influenced by attitudes towards the behaviour, subjective norms, and perceptions of behavioural control (Ajzen, 2001; Tan and Laswad, 2006).

'The TPB proposes that: (i) a student's attitude towards accounting as his/her major (personal factor); (ii) his/her beliefs about important others (referents factor); and (iii) how easy or difficult it is to perform the behaviour (control factor), are predictors of his/her intentions to major in a particular discipline and his/her ultimate decision to choose that major' (Tan and Laswad, 2006, p.174).

After considering and studying the TPB theoretical framework, the accounting literature and the results of the researcher's pilot study, this study intends to supplement such limited research and investigates accounting students' perceptions and interest in the management accounting profession. It also examines the factors that influence students' interest. Some suggestions to remedy the lack of interest in such very important major in accounting are made, not only in reference to Jordan but worldwide. Hence, the following hypotheses have been formulated to achieve the purpose of this study:

H1: There is a lack of interest among accounting students in pursuing management accounting professional certificates in the future.

H2: There is a negative impact of the 'influence of job opportunities and income factor' upon students' interest in pursuing management accounting professional certificates in the future.

H3: There is a negative impact of the 'influence of family and friends' factor' upon students' interests in pursuing management accounting professional certificates in the future.

H4: There is a negative impact of the 'influence of instructors' factor' upon students' interests in pursuing management accounting professional certificates in the future. 
H5: There is a negative impact of the 'influence of colleagues' factor' upon students' interests in pursuing management accounting professional certificates in the future.

H6: There is a negative impact of the 'influence of management accounting courses' factor' upon students' interests in pursuing management accounting professional certificates in the future.

\section{Research method}

\subsection{Research subjects and design}

A field experiment was designed to identify accounting students' perceptions on management accounting as a future career. The experiment, using a questionnaire instrument, was designed to gather general information about respondent accounting students in its first part (gender, university level, having accountants in the family or friends, rank of accounting major among other majors when student applied for university, recommendation for others to pursue management accounting professional certificates, and student's performance in management accounting course (s)). In the second part of the questionnaire, the researcher asked students three types of questions: 1) their interest in pursuing professional accounting qualifications; 2) the importance of selected factors decreasing students' interest in the management accounting profession after graduation; and 3) the importance of some suggestions (factors), which may increase students' interest the in management accounting profession after graduation (see the questionnaire in Appendix A). Several academics and colleagues reviewed the current instrument and found the instrument to be satisfactory and to fulfil the study's objectives. The study was administered to seniors accounting students at two Jordanian public universities that have an undergraduate accounting programme. Students were instructed that the study was voluntary but that their participation was important and appreciated.

\subsection{Research instrument and data collection}

The researcher designed the questionnaire in order to achieve the study's purpose, answer the study's questions and test formulated hypotheses. The questionnaire was pilot tested on a small group of accounting students in both universities equally, for rendering results valid and reliable. The questionnaire was answered within twenty minutes without any difficulties and ambiguous questions.

The survey was administered in classes of advanced accounting courses to ensure that only senior (advanced) accounting students took part in the survey. One hundred twenty five questionnaires were delivered to students in both universities and all of were returned because it was delivered and received during class time. Only 118 of them were usable and 7 were omitted from the study, because they were not fully completed or answered.

The current study was conducted relying on several main points. First, the findings of Hutaibat (2005) indicate the need to study the lack of interest in management accounting in Jordan. Hutaibat in his study clearly shows the low interest in the management accounting profession among respondents. Other international studies have shown the same findings of Hutaibat (2005), such as Warrick et al. (2010), Joshi et al. (2008), Nelson et al. (2002) and Giladi et al. (2001). Second, the findings of the pilot study were available prior to the current study, in order to examine interest in management accounting as a future career among accounting students. The pilot study of fifteen accounting students was conducted to ensure the existence of the current study's problem and questions. Students were asked about the main factors that may influence their interest in management accounting as a future career and their suggestions in order to increase such interest. Third, the apparent drift in the current management accounting literature, as some academics suggest management accounting to have an ever-growing presence (Baldvinsdottir et al., 2010), whereas others suggest that a re-orientation is required (Otley, 2008), which might well reflect the varying perceptions of management accounting in different countries and cultural settings (Hoffjan et al., 2009). Considering new developments to introduce a new management accounting qualification, CGMA (CIMA, 2011), it is very interesting to identify what current accounting students perceive of their possible career options and to investigate the factors that influence such choices.

To this end, the current study examined two aspects. Firstly, the extent of Jordanian accounting students' interest in the management accounting profession was examined. Secondly, the factors, that influence accounting students to choose management accounting as their future career and profession, were investigated.

\section{Results and Discussion}

\subsection{General information}

Student respondents were asked general questions first, to confirm their university level and their gender. The results shown in Table 1 present that most respondents (71\%) were male and almost $29 \%$ were female. The study targeted senior accounting students, hence, about $81 \%$ of respondents were in their final year and the rest were in 
their third year. Table 1 also shows that the majority of respondent (59\%) do not have an accountant among their families and friends. More than $70 \%$ have selected the accounting major as their first choice, when they applied for their university study. The researcher asked students whether they would advise others to pursue management accounting professional certificates. The results shown in Table 1 point out that half of the respondents do not recommend others to seek such professional certificates. However, about $41 \%$ of respondent students recommend others to pursue management accounting professional certificates. Table 1 also presents students' performance in management accounting course(s); the majority $(60 \%)$ of respondents have achieved average and upper marks in their course(s).

$<$ Insert Table 1 here $>$

\subsection{Interest in the management accounting profession}

Respondents were asked to reveal their interest in pursuing selected professional accounting qualifications after their graduation. As shown in Table 2 below, the most attractive professional accounting qualification was the JCPA with $80 \%$ (mean $=3.79$ ) of respondents being interested to gain this qualification. The American certificate $(\mathrm{CPA})$ was the second most attractive qualification with $71 \%$ (mean $=3.49$ ) of students being interested, compared to only $45 \%$ (mean $=2.94$ ) of respondent being interested in the British certificate (ACCA). Unfortunately for the management accounting profession, Table 2 shows that the minority of students were interested in management accounting qualifications, such as the American certificate (CMA) with $32 \%$ (mean = $2.78)$ and the British certificate (CIMA) with only $19 \%$ (mean = 2.34). The Arabic certificate (ACPA) was also not popular among accounting students with only $20 \%$ (mean $=1.81)$ of respondents being interested in it. According to these findings, the null hypothesis of hypothesis $\mathbf{H 1}$ can be rejected.

$<$ Insert Table 2 here $>$

These findings are much more optimistic than Hutaibat's (2005) study, since the interest in management accounting is much higher than before. Furthermore, the result of this study is consistent with that of Warrick et al. (2010); Moreover, Joshi et al. (2008); Nelson et al. (2002); and Giladi et al. (2001).

The popularity of CPA, JCPA and ACCA over CMA and CIMA could be for many reasons: firstly, financial accounting and auditing are mandatory, thus widely used in practice; secondly, there is a high local and international demand for JCPA, CPA and ACCA among companies; thirdly, the mandatory requirements (i.e. law requirements) for companies to be audited by JCPAs, CPAs and ACCAs; fourthly, the ignorance of management accounting use and benefits among companies, top management, to a certain extent academics, and accountants in Jordan.

\subsection{Factors influencing students' interest in the management accounting profession}

Participating accounting students were also consulted (using a five-point Likert scale) regarding the importance of selected factors that have influenced their interest in pursuing a management accounting qualification in the future. The findings in Table 3 indicate that the most important factor having discouraged their interest in the management accounting profession among accounting students is the influence of job opportunities and income, with a mean score of $4.14(\mathrm{SD}=1.07)$, with $76 \%$ of respondents rating this factor as 'above average importance' and 'extremely important'. The table also shows that the second important factor having influenced their interest is their family's and friends' opinion, which was considered by $68 \%$ of respondents as an 'above average importance' and 'extremely important' factor, with a mean score of $3.99(\mathrm{SD}=1.36)$. Influence of instructors was ranked third highest in importance, with a mean score of $3.90(\mathrm{SD}=0.85)$. Respondents have ranked the influence of colleagues upon their interest in the management accounting profession as the fourth highest factor, with a mean of $3.45(\mathrm{SD}=0.84)$. The least important factor having decreased accounting students' interest in the management accounting profession was the influence of management accounting courses, with a mean score of $3.04(\mathrm{SD}=1.33)$. The lowest mean of 3.04 regarding the influence of management accounting courses indicates that all the selected factors were recognised as important by most of the respondents. Therefore, according to the above results, the null hypotheses of hypotheses $\mathrm{H2}$; H3; H4; H5; and $\mathrm{H6}$ can be rejected.

$<$ Insert Table 3 here>

The significant negative influence of job opportunities and income upon accounting students' interest in the management accounting profession is not a surprising result; it can be explained by the fact that only few advertised job opportunities for management accounting posts are available in Jordan. Accordingly, the negative influence of other factors (i.e. family and friends, instructors, colleagues) can be easily be explained, as anyone would want the best job opportunities and income for someone they know. However, regarding the negative influence of management accounting courses upon students' interests in this profession can by justified in many 
ways: 1) the heavy workload in such courses could significantly reduce students' interest; 2) the nature of such courses could be difficult for many students and not enjoyable and interesting.; and 3) in connected to instructors' influence, the presentation of the course was such that students were not attracted to the subject matter. In particular the negative influence of courses reflects Bourdieu's (1990) argument that formal education can greatly influence future perceptions and viewpoints.

Comparing previous related studies, the results of this study are consistent with those of Gul et al. (1989), Adams et al. (1994), Felton et al. (1994), Ahmed et al. (1997), Lowe and Simons (1997), and Mauldin et al. (2000). Regarding the important influence of family and friends upon students' interest and decision-making, the findings of the current study are consistent with those of Inman et al. (1989) and Mauldin et al. (2000), but contrast with those of Gul et al. (1989), Hermanson and Hermanson (1995), and Lowe and Simons (1997). Comparing relevant prior studies, the results of this study regarding the important influence of instructors are consistent with those of Hermanson and Hermanson (1995), Geiger and Ogilby (2000), and Mauldin et al. (2000), but contrast with those of Cangelosi et al. (1985) and Gul et al. (1989). Regarding the important influence of management accounting courses upon students' interest and decision-making, the findings of the current study are consistent with those of Cohen and Hanno (1993), Saemann and Crooker (1999), Mauldin et al. (2000), and Allen (2004).

\subsection{Suggestions encourage students' interest in the management accounting profession}

The pilot study of this research pointed out some factors (suggestions) to remedy the lack of interest in the management accounting profession among accounting students in Jordanian universities. Respondents were asked to indicate on a five-point Likert scale to what extent these factors were important to increase students' interest in management accounting. Table 4 shows respondents considered the most important and least important factors to be the support from companies to focus on management accounting, and seminars and workshops in management accounting at universities, respectively with means of 4.31 and 3.52. It is evident from the respondents' points of view that the most important factor able to increase their interest in management accounting profession is the support from companies regarding management accounting, with a mean score of $4.31(\mathrm{SD}=1.18)$. The existence of a local professional management accounting association and qualification was the second most important factor that may enhance accounting students' interest, with a mean of $4.22(\mathrm{SD}=1.08)$. According to the results shown in Table 4, the third important factor with a mean score of $4.12(\mathrm{SD}=1.43)$ was the support of management accounting professional bodies to accounting students, followed by work placement opportunities in management accounting, with a mean of $4.11(\mathrm{SD}=0.54)$. Tutorial courses in solving real problems and real cases in management accounting at universities, and seminars and workshops in management accounting at universities ranked in as the fifth and sixth important factors, which may increase accounting students' interest in the profession, with mean scores of $3.94(\mathrm{SD}=1.50)$ and $3.52(\mathrm{SD}=1.20)$, respectively.

$<$ Insert Table 4 here $>$

The lowest mean score of 3.52 for seminars and workshops in management accounting at universities indicates that all of the above listed factors (suggestions) were recognised as important to enhance the interest in the management accounting profession by most participating students.

\section{Conclusion}

The objective of this study was to examine the interest of accounting students in the management accounting profession after their graduation and selected factors that have influenced their decision and interest. The study has also examined the influence of selected suggestions (factors) that may increase students' interest in pursuing a career in management accounting in the future. The findings clearly indicate that there is a lack of interest in management accounting professional qualifications among accounting students, as opposed to their interest in other professional accounting qualifications, such as JCPA, CPA, and ACCA. Furthermore, the results of this study pointed out that all selected factors have an important negative impact on accounting students' interest in management accounting, with the influence of job opportunities and income being the most important factor. The results have also shown that all six suggestions for improving accounting students' interest in the management accounting profession were highly ranked. In particular, support from companies to pursue a management accounting career is important, which again is connected to the influence of job opportunities and income.

However, such findings have important implications. First, they are very important for international professional management accounting bodies, in particular an issue to be addressed by the new management accounting body and its qualification, CGMA. They should increase their activities and support of universities, companies, and students (for example, funding and administrating seminars and workshops for students and practitioners, and 
through unlimited support of researchers in the management accounting field).This includes financial and non financial support to increase the awareness of such an important discipline among people. This is in line with Bourdieu (1990) who suggests that formal education has a significant influence on perceptions and viewpoints. Furthermore, the Jordanian sector is very US-focussed, regarding both academia and practices, which might explain the low interest in management accounting. The AICPA and CIMA initiative that was introduced to increase management accounting development in the US (CIMA, 2011), might positively affect the Jordanian accounting sector. Also, university curricula are often aligned with American universities, where managerial accounting has a subordinate position, compared to the UK or Germany (Hoffjan et al., 2009).

Second, it is an urgent call for establishing local management accounting institution and qualification which will improve and support the status of management accounting profession in Jordan; and third, management accounting education within colleges and universities has to be more emphasised, connected to real accounting practices and up to date. This conforms to Pierce and O'Dea (2003), who find that often there are significant differences between academia and practice. This can be done for example by giving students more than one management accounting course (e.g. introduction and advanced), teaching from the latest international textbooks and give students the opportunity to practice what they have learned in real life by creating so called 'work placements' opportunities.

One recommendation and suggestion of this study is that close ties should be created between professional accounting bodies, in particular management accounting ones, and academia. This could be done through research cooperation agreements, and seminars and workshops, on a global level, as opposed to focussed on few countries only. On a greater level, it might have to be accepted that, while practices are employed, they are not always neatly fitting into the accountant's tasks (Otley, 2008). This study's findings certainly conform to Otley's (2008) perception that management accounting does currently not feature very strongly, but contrarily the author does not support the notion to just write the conceptual category and its practices off, and provide a re-definition. Rather, relevance should once again be re-introduced (Johnson and Kaplan, 1987), by reconnecting practice and academia. This kind of relationship will definitely build trust and loyalty to the profession starting with the main source of knowledge and information for future management accounting practitioners (i.e. students). It is very encouraging to see that many published management accounting articles have been sponsored by those accounting bodies.

However, the current findings of this study should be interpreted in light of the study's limitations, which include the use of two Jordanian universities only, sample size of students, simple statistical analysis, and that it is a first study conducted on this specific topic. Such limitations may limit the generalisability of the current study's findings.

For future research recommendations, a comparative study of Jordan and more developed countries, such as the UK and the US, is suggested. One very important problem, which should be investigated in future research, is the migration of qualified management accounting academics and professionals searching for better and higher income. Also, the effect of the new global management accounting professional qualification will be worthwhile investigating. Finally, management accounting should re-gain in relevance (Otley, 2008), the upsurge in management accounting studies (Baldvinsdottir et al., 2010) should be maintained and fostered further by seeking future research opportunities to bridge the gap between theory and practice (Pierce and O'Dea, 2003).

\section{References}

Adams, S. J. et al. (1994). Attraction and retention of high-aptitude students in accounting: an exploratory longitudinal study. Issues in Accounting Education, 9(1), 45-58.

Ahmed, K., Alam, K. and Alam, M. (1997). An empirical study of factors affecting accounting students' career choice in New Zealand. Accounting Education, 6 (4), 325-335. http://dx.doi.org/10.1080/096392897331398

Ajzen, I. (1988). Attitudes, Personality and Behavior. Chicago, IL: The Dorsey Press.

Ajzen, I. (2001). Nature and operation of attitudes. Annual Review of Psychology, 52, 27-58. http://dx.doi.org/10.1146/annurev.psych.52.1.27

Ajzen, I. (2002). Perceived behavioural control, self-efficacy, locus of control and the theory of planned behaviour. Journal of Applied Social Psychology, 32(4), 665-683. http://dx.doi.org/10.1111/j.1559-1816.2002.tb00236.x

Allen, C. L. (2004). Business students' perception of the image of accounting. Managerial Auditing Journal, 19(2), 235-258. http://dx.doi.org/10.1108/02686900410517849 
Baldvinsdottir, G., Mitchell, F. and Norreklit, H. (2010). Issues in the relationship between theory and practice in management accounting. Management Accounting Research, 21, 79-82. http://dx.doi.org/10.1016/j.mar.2010.02.006

Bourdieu, P. (1990). The Logic of Practice. Oxford: Polity Press.

Brierley, J. A., Cowton, C. J. and Drury, C. (2001). Research into product costing practice: a European perspective. The European Accounting Review, 10 (2), 215-256.

Cangelosi et al. (1985). The influence of introductory accounting courses on career choices. Delta Phi Epsilon Journal, 27(1), 60-68.

CIMA. (2011). CIMA and AICPA embark on international management accounting initiative. Press Release March 2011, [Online] Available: http://www.cimaglobal.com/About-us/Press-office/Press-releases/2011/March-2011/cima-aicpa-jv/ (August 23, 2011)

Cohen, J. and Hanno, D. M. (1993). An analysis of underlying constructs affecting the choice of accounting as a major. Issues in Accounting Education, 8(2), 219-238.

Drury, C. (2008). Management and Cost accounting, ( $7^{\text {th }}$ edition). London: Cengage Learning.

Drury, C. and Tayles, M. (1994). Product costing in UK manufacturing organizations. The European Accounting Review, 3 (3), 443-469. http://dx.doi.org/10.1080/09638189400000031

Drury, C. and Tayles, M. (1995). Issues arising from surveys of management accounting practice. Management Accounting Research, 6, 267-280. http://dx.doi.org/10.1006/mare.1995.1018

Felton, S., Buhr, N. and Northey, M. (1994). Factors influencing the business student's choice of a career in chartered accountancy. Issues in Accounting Education, (Spring), 131-141.

Fishbein, M. and Ajzen, I. (1975). Belief, Attitude, Intention and Behavior: An Introduction to Theory and Research. Reading, MA: Addison-Wesley.

Gammie, E. and Kirkpatrick, L. (2008). Breaking the link with a university education in the creation of a chartered accountant: The ICAS story. The British Accounting Review, 40 (4), 356-375. http://dx.doi.org/10.1016/j.bar.2008.06.002

Geiger, M. A. and Ogilby, S. M. (2000). The first course in accounting: students' perceptions and their effect on the decision to major in accounting. Journal of Accounting Education, 18(2), 63-78. http://dx.doi.org/10.1016/S0748-5751(00)00011-7

Giladi, K., Amoo, T. and Friedman, H.H. (2001). A survey of accounting majors: Attitudes and opinions. The National Public Accountant, 46 (2), 25-27.

Granlund, M. and Lukka, K. (1998). It's a Small World of Management Accounting Practices. Journal of Management Accounting Research, 10, 153-179.

Gul, F. A. et al. (1989). Factors influencing choice of discipline of study - accountancy, engineering, law and medicine. Accounting and Finance, 29, 93-101. http://dx.doi.org/10.1111/j.1467-629X.1989.tb00105.x

Haldma, T. and Lääts, K. (2002). Contingencies influencing the management accounting practices of Estonian manufacturing companies. Management Accounting Research, 13, 379-400. http://dx.doi.org/10.1006/mare.2002.0197

Hermanson, D. R. and Hermanson, R. H. (1995). Are America's top businesses students steering clear of accounting? Ohio CPA Journal, 54(2), 26-30.

Hoffjan, A., Nevries, P. and Stienemann, R. (2009). Comparative Management Accounting - Literature review on similarities and differences between management accounting in Germanic and Anglophone countries', in Berens, W./Hoffjan, A./Burgartz, T. (Hrsg.): Controlling in einem globalen Markt, Vol. 37. Edition Controlling und Management, Peter Lang Verlag, pp. 113-146.

Hopper, T., Kirkham, L., Scapens, R. and Turley, S. (1992). Does financial accounting dominate management accounting-a research note. Management Accounting Research, 3 (4), 307-311. http://dx.doi.org/10.1016/S1044-5005(92)70019-5

Hopper, T., Northcott, D. and Scapens, R. (2007). Issues in Management Accounting, (3 ${ }^{\text {rd }}$ edition). Harlow: Pearson Education. 
Hutaibat, K. (2005). Management accounting practices in Jordan - a contingency approach. Unpublished PhD thesis, University of Bristol, UK.

Inman, B. C. et al. (1989). Square pegs in round holes: are accounting students well-suited to today's accounting profession?. Issues in Accounting Education, 4(1), 29-47.

James, K.L. and Hill, C. (2009). Race and the development of career interest in accounting. Journal of Accounting Education, 27, 210-222. http://dx.doi.org/10.1016/j.jaccedu.2010.07.005

Johnson, H. and Kaplan, R. (1987). Relevance Lost: The Rise and Fall of Management Accounting. Harvard Business School Press, Boston, MA.

Joshi, P.L., Bremser, W.G. and Al-Ajmi, J. (2008). Perceptions of accounting professionals in the adoption and implementation of a single set of global accounting standards: Evidence from Bahrain. Advances in Accounting, incorporating Advances in International Accounting, 24, 41-48. http://dx.doi.org/10.1016/j.adiac.2008.05.007

Langfield-Smith, K. (2008). Strategic management accounting: how far have we come in 25 years? Accounting, Auditing and Accountability Journal, 21 (2), 204-228. http://dx.doi.org/10.1108/09513570810854400

Lowe, D. R. and Simons, K. (1997). Factors influencing choice of business majors - some additional evidence: a research note. Accounting Education: an international journal, 6(1), 39-45.

Mauldin, S. et al. (2000). The accounting principles instructor's influence on students' decision to major in accounting. Journal of Education for Business, 142-148. http://dx.doi.org/10.1080/08832320009599005

McKenzie, K.S. (1992). Attitudes toward governmental accounting: a second look. The Government Accountants Journal, (Winter), 69-78.

Milne, M., Guthrie, J. and Parker, L. (2008). Into the light and engagement: Two decades of interdisciplinary perspectives on accounting, auditing and accountability research. Accounting, Auditing and Accountability Journal, 21 (2), 117-128. http://dx.doi.org/10.1108/09513570810854374

Nelson, I.T., Vendrzyk, V.P., Quirin, J.J. and Allen, R.D. (2002). No, the sky is not falling: evidence of accounting student characteristics at fsa schools, 1995-2000. Issues in Accounting Education, (August), 269-287.

Otley, D. (1983). Behavioural and Organisational Research in Management Accounting, in Cooper, D., Scapens, R., and Arnold, J., (ed.) Management Accounting Research and Practice, occasional papers series. London, The Chartered Institute of Management Accountants, pp. 136-158.

Otley, D. (2008). Did Kaplan and Johnson get it right? Accounting, Auditing and Accountability Journal, 21 (2), 229-239. http://dx.doi.org/10.1108/09513570810854419

Pierce, B. and O'Dea, T. (2003). Management accounting information and the needs of managers: Perceptions of managers and accountants compared. The British Accounting Review, 35 (3), 257-290. http://dx.doi.org/10.1016/S0890-8389(03)00029-5

Saemann,G.P. and Crooker, K. J. (1999). Student perceptions of the profession and its effect on decisions to major in accounting. Journal of Accounting Education, 17, 1-22. http://dx.doi.org/10.1016/S0748-5751(99)00007-X

Scapens, R., Gameil, M. and Cooper, D. (1983). Accounting Information for Pricing Decisions: An Empirical Study, in Cooper, D., Scapens, R., and Arnold, J., (ed.) Management Accounting Research and Practice, occasional papers series. London, The Chartered Institute of Management Accountants, pp. 283-306.

Simons, K. A. et al. (2004). Comprehensive literature review: factors influencing choice of accounting as a major. Journal of the Academy of Business Education, 5(Fall), 97-110.

Stice, J. D. and Swain, M. R. (1997). The effect of performance on the decision to major in accounting. Journal of Education for Business, 73(1), 54-69. http://dx.doi.org/10.1080/08832329709601616

Tan, L.M. and Laswad, F. (2006). Students' Beliefs, Attitudes and Intentions to Major in Accounting. Accounting Education: an international journal, 15 (2), 167-187.

Warrick, C.S., Daniels, B. and Scott, C. (2010). Accounting students' perceptions on employment opportunities. Research in Higher Education Journal, 7 (May), 1-10.

Wolk, C. M. and Cates, T. A. (1994). Problem-solving styles of accounting students: are expectations of innovation reasonable? Journal of Accounting Education, 12(4), 269-281. http://dx.doi.org/10.1016/0748-5751(94)90022-1 
Table 1. General information

\begin{tabular}{|c|c|c|c|c|}
\hline $\begin{array}{c}\text { Question } \\
\text { (Sample 118) } \\
\end{array}$ & Frequency & $\begin{array}{c}\text { Percent } \\
(\%)\end{array}$ & Mean & $\begin{array}{c}\text { Std. } \\
\text { Deviation }\end{array}$ \\
\hline $\begin{array}{l}\text { Gender: } \\
\text { Male } \\
\text { Female }\end{array}$ & $\begin{array}{l}84 \\
34\end{array}$ & $\begin{array}{l}71.2 \\
28.8 \\
\end{array}$ & 1.2881 & .4548 \\
\hline $\begin{array}{l}\text { University level: } \\
\text { Third year } \\
\text { Final year }\end{array}$ & $\begin{array}{l}23 \\
95\end{array}$ & $\begin{array}{l}19.5 \\
80.5 \\
\end{array}$ & 3.8050 & .3970 \\
\hline $\begin{array}{l}\text { Accountant (s) among family: } \\
\text { Yes } \\
\text { No }\end{array}$ & $\begin{array}{l}48 \\
70\end{array}$ & $\begin{array}{l}40.7 \\
59.3\end{array}$ & 1.5932 & .4933 \\
\hline $\begin{array}{l}\text { Rank of accounting major: } \\
\text { First choice } \\
\text { Second choice } \\
\text { Third choice }\end{array}$ & $\begin{array}{l}83 \\
24 \\
11\end{array}$ & $\begin{array}{c}70.3 \\
20.3 \\
9.3\end{array}$ & 1.3898 & .6542 \\
\hline $\begin{array}{l}\text { Management accounting Professional } \\
\text { certificates: } \\
\text { Not recommended } \\
\text { Neutral } \\
\text { Recommended } \\
\text { Extremely recommended }\end{array}$ & $\begin{array}{l}59 \\
11 \\
36 \\
12 \\
\end{array}$ & $\begin{array}{c}50.0 \\
9.3 \\
30.5 \\
10.2 \\
\end{array}$ & 3.0085 & 1.1055 \\
\hline $\begin{array}{l}\text { Students' performance in management } \\
\text { accounting course (s): } \\
\text { Not good } \\
\text { Average } \\
\text { Good } \\
\text { Extremely good }\end{array}$ & $\begin{array}{l}47 \\
12 \\
35 \\
24\end{array}$ & $\begin{array}{l}39.8 \\
10.2 \\
29.7 \\
20.3\end{array}$ & 3.3051 & 1.1948 \\
\hline
\end{tabular}

Table 2. Respondents' interest in selected professional accounting qualifications

\begin{tabular}{|c|c|c|c|c|c|c|c|c|}
\hline \multirow{2}{*}{$\begin{array}{c}\text { Professional accounting } \\
\text { qualifications }\end{array}$} & \multicolumn{5}{|c|}{ Interest level* } & \multirow{2}{*}{$\begin{array}{c}\text { Mean } \\
\text { (rank) }\end{array}$} & \multirow[t]{2}{*}{ Median } & \multirow[t]{2}{*}{ S.D } \\
\hline & $\begin{array}{c}1 \\
\% \\
(\#) \\
\end{array}$ & $\begin{array}{c}\mathbf{2} \\
\% \\
(\#) \\
\end{array}$ & $\begin{array}{c}3 \\
\% \\
(\#) \\
\end{array}$ & $\begin{array}{c}4 \\
\% \\
(\#) \\
\end{array}$ & $\begin{array}{c}\mathbf{5} \\
\% \\
(\#) \\
\end{array}$ & & & \\
\hline JCPA & $\begin{array}{c}00.0 \\
(0)\end{array}$ & $\begin{array}{l}10.2 \\
(12) \\
\end{array}$ & $\begin{array}{l}10.2 \\
(12) \\
\end{array}$ & $\begin{array}{l}70.3 \\
(83) \\
\end{array}$ & $\begin{array}{c}9.3 \\
(11) \\
\end{array}$ & $\begin{array}{c}3.79 \\
\text { (1) }\end{array}$ & 4.00 & 0.75 \\
\hline ACPA & $\begin{array}{l}69.5 \\
(82) \\
\end{array}$ & $\begin{array}{c}00.0 \\
(0)\end{array}$ & $\begin{array}{l}10.2 \\
(12)\end{array}$ & $\begin{array}{l}20.3 \\
(24)\end{array}$ & $\begin{array}{c}00.0 \\
(0)\end{array}$ & $\begin{array}{c}1.81 \\
(6)\end{array}$ & 1.00 & 1.26 \\
\hline CPA & $\begin{array}{l}3.4 \\
(4)\end{array}$ & $\begin{array}{l}23.7 \\
(28)\end{array}$ & $\begin{array}{l}1.7 \\
(2)\end{array}$ & $\begin{array}{l}62.7 \\
(74) \\
\end{array}$ & $\begin{array}{c}8.5 \\
(10)\end{array}$ & $\begin{array}{c}3.49 \\
(2)\end{array}$ & 4.00 & 1.05 \\
\hline $\mathbf{A C C A}$ & $\begin{array}{l}3.4 \\
(4)\end{array}$ & $\begin{array}{l}50.0 \\
(59)\end{array}$ & $\begin{array}{l}1.7 \\
(2)\end{array}$ & $\begin{array}{l}39.0 \\
(46)\end{array}$ & $\begin{array}{l}5.9 \\
(7)\end{array}$ & $\begin{array}{c}2.94 \\
(3)\end{array}$ & 2.00 & 1.13 \\
\hline CMA & $\begin{array}{c}8.5 \\
(10)\end{array}$ & $\begin{array}{l}59.3 \\
(70)\end{array}$ & $\begin{array}{c}00.0 \\
(0)\end{array}$ & $\begin{array}{l}10.2 \\
(12)\end{array}$ & $\begin{array}{l}22.0 \\
(26)\end{array}$ & $\begin{array}{c}2.78 \\
(4)\end{array}$ & 2.00 & 1.37 \\
\hline CIMA & $\begin{array}{l}7.6 \\
(9)\end{array}$ & $\begin{array}{l}71.2 \\
(84)\end{array}$ & $\begin{array}{l}2.5 \\
(3)\end{array}$ & $\begin{array}{l}16.9 \\
(20)\end{array}$ & $\begin{array}{l}1.7 \\
(2)\end{array}$ & $\begin{array}{c}2.34 \\
(\mathbf{5})\end{array}$ & 2.00 & 0.91 \\
\hline
\end{tabular}

$* 1=$ Not interested, $2=$ Below average interest, $3=$ Average interest, $4=$ Above average interest, $5=$ Extremely interested. 
Table 3. Factors that have decreased accounting students' interest in the management accounting profession

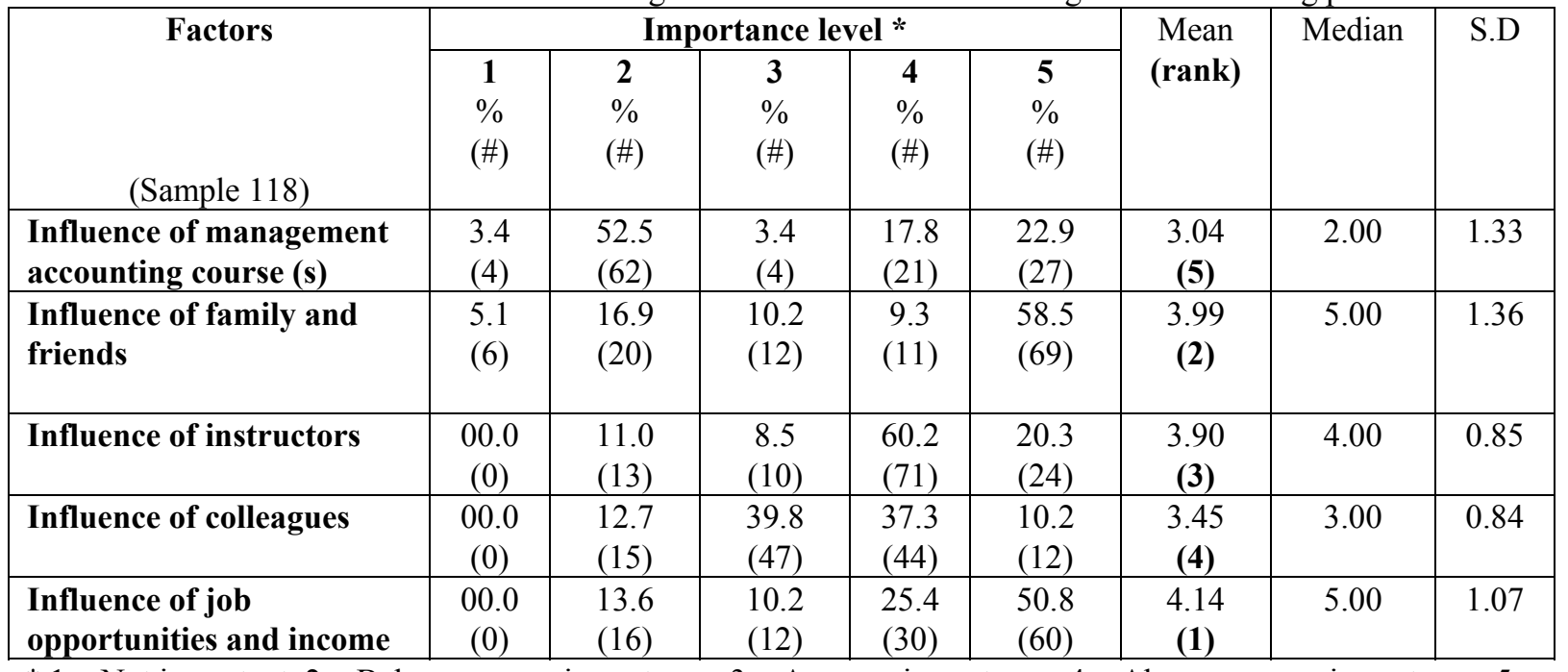

$* 1=$ Not important, $2=$ Below average importance, $3=$ Average importance, $4=$ Above average importance, $5=$ Extremely important.

Table 4. Factors that may increase accounting students' interest in the management accounting profession

\begin{tabular}{|c|c|c|c|c|c|c|c|c|}
\hline \multirow[b]{2}{*}{ (Sample 118) } & \multicolumn{5}{|c|}{ Importance level * } & \multirow{2}{*}{$\begin{array}{c}\text { Mean } \\
\text { (rank) }\end{array}$} & \multirow[t]{2}{*}{ Median } & \multirow[t]{2}{*}{ S.D } \\
\hline & $\begin{array}{l}\mathbf{1} \\
\% \\
(\#)\end{array}$ & $\begin{array}{c}\mathbf{2} \\
\% \\
(\#)\end{array}$ & $\begin{array}{c}3 \\
\% \\
(\#)\end{array}$ & $\begin{array}{c}\mathbf{4} \\
\% \\
(\#)\end{array}$ & $\begin{array}{l}\mathbf{5} \\
\% \\
(\#)\end{array}$ & & & \\
\hline $\begin{array}{l}\text { Support of management } \\
\text { accounting professional } \\
\text { bodies to accounting } \\
\text { students }\end{array}$ & $\begin{array}{c}9.3 \\
(11)\end{array}$ & $\begin{array}{l}10.2 \\
(12)\end{array}$ & $\begin{array}{l}10.2 \\
(12)\end{array}$ & $\begin{array}{c}00.0 \\
(0)\end{array}$ & $\begin{array}{l}70.3 \\
(83)\end{array}$ & $\begin{array}{c}4.12 \\
\text { (3) }\end{array}$ & 5.00 & 1.43 \\
\hline $\begin{array}{l}\text { Support from companies } \\
\text { to pursue management } \\
\text { accounting profession }\end{array}$ & $\begin{array}{c}00.0 \\
(0)\end{array}$ & $\begin{array}{l}19.5 \\
(23)\end{array}$ & $\begin{array}{c}00.0 \\
(0)\end{array}$ & $\begin{array}{l}10.2 \\
(12)\end{array}$ & $\begin{array}{l}70.3 \\
(83)\end{array}$ & $\begin{array}{c}4.31 \\
\text { (1) }\end{array}$ & 5.00 & 1.18 \\
\hline $\begin{array}{l}\text { Seminars and workshops } \\
\text { in management accounting } \\
\text { at universities }\end{array}$ & $\begin{array}{c}9.3 \\
(11)\end{array}$ & $\begin{array}{l}10.2 \\
(12)\end{array}$ & $\begin{array}{l}20.3 \\
(24)\end{array}$ & $\begin{array}{l}39.8 \\
(47)\end{array}$ & $\begin{array}{l}20.3 \\
(24)\end{array}$ & $\begin{array}{c}3.52 \\
(6)\end{array}$ & 4.00 & 1.20 \\
\hline $\begin{array}{l}\text { The existence of local } \\
\text { professional management } \\
\text { accounting association and } \\
\text { qualification }\end{array}$ & $\begin{array}{c}00.0 \\
(0)\end{array}$ & $\begin{array}{l}10.2 \\
(12)\end{array}$ & $\begin{array}{l}18.6 \\
(22)\end{array}$ & $\begin{array}{l}10.2 \\
(12)\end{array}$ & $\begin{array}{l}61.0 \\
(72)\end{array}$ & $\begin{array}{c}4.22 \\
\text { (2) }\end{array}$ & 5.00 & 1.08 \\
\hline $\begin{array}{l}\text { Tutorial courses in solving } \\
\text { real problems and real } \\
\text { cases in management } \\
\text { accounting at universities }\end{array}$ & $\begin{array}{c}9.3 \\
(11)\end{array}$ & $\begin{array}{l}19.5 \\
(23)\end{array}$ & $\begin{array}{c}00.0 \\
(0)\end{array}$ & $\begin{array}{l}10.2 \\
(12)\end{array}$ & $\begin{array}{l}61.0 \\
(72)\end{array}$ & $\begin{array}{c}3.94 \\
(5)\end{array}$ & 5.00 & 1.50 \\
\hline $\begin{array}{l}\text { Work placements } \\
\text { opportunities in } \\
\text { management accounting } \\
\text { for accounting students }\end{array}$ & $\begin{array}{c}00.0 \\
(0)\end{array}$ & $\begin{array}{c}00.0 \\
(0)\end{array}$ & $\begin{array}{c}9.3 \\
(11)\end{array}$ & $\begin{array}{l}70.3 \\
(83)\end{array}$ & $\begin{array}{l}20.3 \\
(24)\end{array}$ & $\begin{array}{l}4.11 \\
\text { (4) }\end{array}$ & 4.00 & 0.54 \\
\hline
\end{tabular}

$* 1=$ Not important, $2=$ Below average importance, $3=$ Average importance, $4=$ Above average importance, $5=$ Extremely important. 
Appendix A: (The questionnaire instrument)

\section{PART ONE: \\ General Information}

The information in this part is general information. (Please answer all questions).

P.1.1) What is your gender?

(Please tick one box only)

Male

Female

P.1.2) What is your current university level?

(Please tick one box only)
First year (freshman)
Third year
Second year (sophomore)

P.1.3) What is the name of your university?

(Please tick one box only)

$\mathrm{X}$

P.1.4) Do you have accountants among your family or friends?

(Please tick one box only)

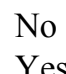

P.1.5) What was the rank of accounting major among other majors when you applied for university acceptance (offers)?

First choice

Second choice

Third choice

Fourth choice

Fifth choice

Other (please specify)......

P.1.6) Indicate to what extents do you advice others to pursue management accounting professional certificate? (Please tick one box only)

\begin{tabular}{|c|c|c|c|c|}
\hline $\begin{array}{c}\text { Extremely not } \\
\text { recommended }\end{array}$ & Not recommended & Neutral & Recommended & $\begin{array}{c}\text { Extremely } \\
\text { recommended }\end{array}$ \\
\hline & & & & \\
\hline
\end{tabular}

P.1.7) Indicate and rank your performance in the management accounting course (s)?

(Please tick one box only)

\begin{tabular}{|c|c|c|c|c|}
\hline $\begin{array}{c}\text { Extremely not } \\
\text { good }\end{array}$ & Not good & Average & Good & Extremely good \\
\hline & & & & \\
\hline
\end{tabular}

\section{PART TWO:}

Factors that may influence your interest in the management accounting profession.

The information in this part is about the factors that may influence your interest of pursuing the management accounting profession after your graduation.

P.2.1) To what extent are you interested in the following professional accounting qualifications which you may pursue in the future, if any?

(You may tick more than one box)

\begin{tabular}{|c|c|c|c|c|c|}
\hline $\begin{array}{c}\text { Professional accounting } \\
\text { qualifications }\end{array}$ & $\begin{array}{c}\text { Extremely not } \\
\text { interested } \\
\mathbf{1} \\
\end{array}$ & $\begin{array}{c}\text { Not } \\
\text { interested }\end{array}$ & Not sure & Interested & $\begin{array}{c}\text { Extremely } \\
\text { interested } \\
\mathbf{5} \\
\end{array}$ \\
\hline $\begin{array}{l}\text { Jordanian certified public } \\
\text { accountant (JCPA) }\end{array}$ & & & & & \\
\hline $\begin{array}{l}\text { Arabic certified public } \\
\text { accountant (ACPA) }\end{array}$ & & & & & \\
\hline $\begin{array}{l}\text { American certified public } \\
\text { accountant (CPA) }\end{array}$ & & & & & \\
\hline $\begin{array}{l}\text { British certified public } \\
\text { accountant (ACCA) }\end{array}$ & & & & & \\
\hline $\begin{array}{l}\text { American certified management } \\
\text { accountant (CMA) }\end{array}$ & & & & & \\
\hline
\end{tabular}




\begin{tabular}{|l|l|l|l|l|l|}
\hline $\begin{array}{l}\text { British certified management } \\
\text { accountant (CIMA) }\end{array}$ & & & & & \\
\hline $\begin{array}{l}\text { Other (please } \\
\text { specify)............ }\end{array}$ & & & & & \\
\hline
\end{tabular}

P.2.2) Complete the table by ticking the appropriate box.

How strongly have the following factors decreased your interest in management accounting profession?

\begin{tabular}{|l|c|c|c|c|c|}
\hline \multicolumn{1}{|c|}{ Factors } & $\begin{array}{c}\text { Not } \\
\text { important } \\
\mathbf{1}\end{array}$ & $\begin{array}{c}\text { Below } \\
\text { average } \\
\text { importance }\end{array}$ & $\begin{array}{c}\text { Average } \\
\text { importance }\end{array}$ & $\begin{array}{c}\text { Above } \\
\text { average } \\
\text { importance }\end{array}$ & $\begin{array}{c}\text { Extremely } \\
\text { important } \\
\mathbf{5}\end{array}$ \\
\hline $\begin{array}{l}\text { Influence of job opportunities and } \\
\text { income. }\end{array}$ & & & & & \\
\hline Influence of family and friends. & & & & & \\
\hline Influence of your Instructors. & & & & & \\
\hline Influence of your colleagues. & & & & & \\
\hline $\begin{array}{l}\text { Influence of management } \\
\text { accounting course (s). }\end{array}$ & & & & & \\
\hline Others if any (please specify). & & & & & \\
\hline
\end{tabular}

P.2.3) Complete the table by ticking the appropriate box.

How strongly may the following factors increase your interest in management accounting profession?

\begin{tabular}{|l|c|c|c|c|c|}
\hline \multicolumn{1}{|c|}{ Factors } & $\begin{array}{c}\text { Not } \\
\text { important } \\
\text { 1 }\end{array}$ & $\begin{array}{c}\text { Below } \\
\text { average } \\
\text { importance }\end{array}$ & $\begin{array}{c}\text { Average } \\
\text { importance }\end{array}$ & $\begin{array}{c}\text { Above } \\
\text { average } \\
\text { importance }\end{array}$ & $\begin{array}{c}\text { Extremely } \\
\text { important } \\
\mathbf{5}\end{array}$ \\
\hline $\begin{array}{l}\text { Tutorial courses in solving real } \\
\text { problems and cases in } \\
\text { management accounting at } \\
\text { universities. }\end{array}$ & & & & & \\
\hline $\begin{array}{l}\text { Seminars and workshops in } \\
\text { management accounting at } \\
\text { universities. }\end{array}$ & & & & & \\
\hline $\begin{array}{l}\text { Placements opportunities in } \\
\text { management accounting for } \\
\text { accounting students. }\end{array}$ & & & & & \\
\hline $\begin{array}{l}\text { The existence of local } \\
\text { professional management } \\
\text { accounting association and } \\
\text { qualification. }\end{array}$ & & & & & \\
\hline $\begin{array}{l}\text { Support from management } \\
\text { accounting professional bodies to } \\
\text { accounting students. }\end{array}$ & & & & & \\
\hline $\begin{array}{l}\text { Support from companies to } \\
\text { pursue the management } \\
\text { accounting profession. }\end{array}$ & & & & & \\
\hline Others if any (please specify). & & & & & \\
\hline
\end{tabular}

Many thanks for participated in this study

Good luck in your future career

The Researcher 